\title{
Appropriability: a key to opening innovation internationally?
}

\author{
loana Stefan* and Lars Bengtsson \\ Department of Industrial Engineering and Management, \\ University of Gävle, \\ Sweden \\ Email: ioana.stefan@hig.se \\ Email: lars.bengtsson@hig.se \\ *Corresponding author
}

\begin{abstract}
This study focuses on the tense appropriability-openness relationship, defined by some as paradox. Based on an international survey of 415 manufacturing firms, we investigate how the use of different kinds of intellectual property protection mechanisms (IPPMs) affects interfirm R\&D collaboration while considering partner location in the analysis as well. Our results show that the use of formal, semi-formal or informal IPPMs has different effects on openness in terms of partner variety and depth of collaboration with academic partners, value chain partners and competitors. Moreover, when considering location we uncover previously hidden appropriability-openness liaisons showing that semi-formal or informal IPPMs are mainly valid in relation to national partners, whereas formal appropriability explains international collaborations. One implication of the study is that to better understand the appropriability-openness relationship it is imperative to differentiate between national and international settings. We further suggest that the potential paradox delineating this relationship has a geographical dimension.
\end{abstract}

Keywords: appropriability; intellectual property protection mechanisms; IPPMs; inter-firm collaboration; paradox of openness; R\&D collaboration; international collaboration; open innovation; partner location; partner breadth; variety; partner depth; survey.

Reference to this paper should be made as follows: Stefan, I. and Bengtsson, L. (2016) 'Appropriability: a key to opening innovation internationally?', Int. J. Technology Management, Vol. 71, Nos. 3/4, pp.232-252.

Biographical notes: Ioana Stefan is a doctoral student at the University of Gävle and KTH Royal Institute of Technology. Her primary research focus is the role of intellectual property protection mechanisms in open innovation collaborations, including the investigation of appropriability-openness tensions. Aside from her doctoral studies, she is engaged in further research projects where she contributes by e.g., performing patent analyses or investigating technology trends.

Lars Bengtsson is a Professor in Innovation Management at the University of Gävle, Sweden and a Docent at The KTH Royal Institute of Technology. He has published articles and books on the subjects of innovation management, knowledge integration, manufacturing strategies and outsourcing. He currently leads research focusing on open innovation, supply chain management, human lean and rapid innovators in emerging economies. 
This paper is a revised and expanded version of a paper entitled 'Global open innovation: the effects of IPRs and contracts' presented at the 15th International CINet Conference, Budapest, Hungary, 7-9 September 2014.

\section{Introduction}

Firms increasingly rely on external sources of knowledge, as internal organisational knowledge often proves to be insufficient for maintaining a competitive edge (see, e.g., Cassiman and Veugelers, 2006; Chesbrough, 2003; Rigby and Zook, 2002). Enabling streams of knowledge to flow across organisational boundaries is, however, not without challenges (Chesbrough and Bogers, 2014). One such challenge concerns the tensions between appropriability and openness to collaboration (e.g. Hertzfeld et al., 2006), at times in the utmost form of paradox (see Arrow, 1962; Laursen and Salter, 2014). Previous research provides no clear-cut answers how to solve this challenge. Additionally, the literature on appropriability has been rather biased, focusing extensively on patents and secrecy, while ignoring other types of intellectual property protection (Amara et al., 2008; Hall et al., 2014). Thus, further investigation is needed on how openness relates to the choice of different kinds of appropriability mechanisms. In this study we differentiate between formal, semi-formal and informal intellectual property protection mechanisms (IPPMs).

Researchers acknowledge that protecting inventions via formal and semi-formal IPPMs across multiple territories (countries) can become a rather complex and costly process (see, e.g., Lee, 2014; Trimble, 2015) and strongly affects the decision to collaborate across national boundaries (Hagedoorn et al., 2005). Indeed, the challenge of knowledge flows across firm boundaries has become even more evident due to the increasingly global character of inter-firm collaborations (Bititci et al., 2012; Dussauge and Garrette, 1995). This is because rising globalisation has made the tensions between globalised networks and the patchwork of national intellectual property (IP) laws more obvious (Geller, 1998; Peukert, 2012). However, the critical 'territorial' character of certain types of IPPMs has scarcely been considered alongside appropriability issues in organisational studies. In the few studies take the territoriality aspect into account when investigating appropriability and openness for collaboration, the focus is restricted to either one particular IPPM (Hagedoorn et al., 2005), or few specific types of partner (Schmiele and Sofka, 2007), or there is a lack of distinction between different types of partners (Hagedoorn et al., 2005; Neuhäusler, 2012). Evidence is scarce on how the use of different IPPMs is linked to collaboration with various types of partners in national and international settings.

The intricacies of cross-border inter-firm collaborations have also been approached in other streams of organisational studies, yet those studies have mostly analysed location separately from appropriability issues. Undoubtedly the location of partners in collaboration can constitute a dilemma in itself. On the one hand, purchasing literature indicates benefits of global sourcing and collaboration such as enabling access to leading knowledge and technology (see, e.g., Kotabe et al., 2008). On the other hand, studies on advanced product development show that innovation and knowledge integration processes are characterised by fuzzy interfaces between different technologies and competencies, a complexity that requires proximity, co-location and integration of key 
activities (e.g. Huang and Rice, 2013; Liu et al., 2013). This dilemma underpins the needs to analyse how partner location moderates the use of IPPMs in cross-border collaboration.

The purpose of this study is to investigate how appropriability affects openness while taking into account the location of partners in either national or international settings. The analysis is done in two steps. First we investigate how the choice between three different types of IPPMs affects partner selection and depth of collaboration with different types of partners. Next we seek to fill a broader gap in research by exploring the effects partners' location has on the appropriability-openness relationship. We distill two research questions from the following literature review, and then investigate them via an international survey on open innovation (OI) conducted in 415 manufacturing firms in three European countries.

\section{Literature review}

\subsection{The appropriability-openness relationship}

Though OI has been described as 'old wine in new bottles' (Trott and Hartmann, 2009), the concept introduced by Chesbrough (2003) has attracted a great deal of attention from both scholars and practitioners (Chesbrough and Bogers, 2014). Furthermore, the relationships between firms continue to be a current research topic, particularly given the fast-paced business environments and the increasing difficulty for modern firms to source their innovation entirely internally (see, e.g., Cassiman and Veugelers, 2006; Rigby and Zook, 2002). Although OI was initially described as either inbound (outside-in) or outbound (inside-out) (Chesbrough, 2003), the coupled OI process (Gassmann and Enkel, 2004) and the interactive coupled process (Chesbrough et al., 2014) have been subsequently added to this classification. We analyse OI from the inbound perspective. Despite extensive research in OI, the concept of openness has not yet been rigorously defined (Dahlander and Gann, 2010). Previous studies suggested quantifying openness by measuring the variety of external innovation partners and the depth of collaboration with those partners (Laursen and Salter, 2006), the phase of the innovation process in which the collaboration takes place (see, e.g., Lazzarotti et al., 2011) or the content of collaboration (Huizingh, 2011). Further dimensions might also be relevant when exploring openness. In this study we choose to focus on the variety and depth of collaboration with different types of partners as a consequence of the direct link between the territorial character of some appropriability mechanisms and the two abovementioned dimensions of openness. The territoriality of IP laws and the effects thereof across national borders would likely be less visible if analysed along with other dimensions of openness, such as phase or content of collaboration. OI has more recently defined as "a distributed innovation process based on purposively managed knowledge flows across organizational boundaries, using pecuniary and non-pecuniary mechanisms in line with the organization's business model" [Chesbrough and Bogers, (2014), p.27]. This definition accentuates the fact that when organisations collaborate for innovation, boundaries between them must be bridged. However, when firms' boundaries become open and the likelihood of unintended spillovers increases, the internal knowledge of the firm must be properly managed and protected. Teece (1986) dubbed this the 
appropriability regime, i.e. "the environmental factors ... that govern an innovator's ability to capture the profits generated by an innovation" (p.287).

A notable dilemma regarding appropriability in the context of OI is the openness paradox (see Laursen and Salter, 2005a, 2014), which draws from Arrow's (1962) disclosure paradox. The initial paradox described the tension between the information a potential seller reveals about an innovation and the willingness of a potential buyer to acquire this innovation. Such appropriability challenges are enhanced in OI contexts. While one stream of literature suggests that a firm's increased openness obviates the need for appropriability mechanisms (see, e.g., Von Hippel, 2005), opposing views suggest that protecting intellectual property in OI is crucial (e.g. Hagedoorn and Ridder, 2012). Therefore, there is a need to further investigate the appropriability-openness relationship (Laursen and Salter, 2014).

One difficulty concerning this investigation is the causality of the appropriabilityopenness liaison. Several scholars had suggested that the means of appropriating benefits from their innovations (often in the form of various types of IPPMs) strongly influences the degree of openness firms have towards external partners in innovation (see, e.g., Laursen and Salter, 2014). In the current study we follow this stream of literature and explore the perspective on the appropriability-openness relationship that regards the choice of IPPMs as a determinant for the openness preference. This does not exclude the existence of the reverse logic, but we leave this investigation to further research. In fact, several researchers argue that the causality of the appropriability-openness relationship could go either way, while firms' strategies almost inevitably evolve over time, and that the factors affecting this relationship may determine the direction of the causality (see, e.g., Laursen and Salter, 2014; Miozzo et al., 2015).

In previous research, appropriability has usually been illustrated by various IPPMs, often classified as either formal or informal, that firms use to protect their knowledge and innovations. However, prior studies have argued that the role certain mechanisms, i.e. patents, have goes beyond protection and may include various coordination functions, for instance: signalling, trading technology, acting as 'legal bargaining chips', enabling interfirm collaboration (Penin, 2005) or acting as codes for knowledge (Burk, 2008). Patents are even used to measure technology transfer in certain types of collaboration, e.g. industry-university collaboration (see Schartinger et al., 2002). The formal IPPMs considered in our study are patents, industrial designs, trademarks and copyrights (see, e.g., Laursen and Salter, 2005b). The list of informal IPPMs is more extensive (e.g. PRO INNO Europe, 2007). Prior studies mainly regard secrecy as an informal IPPM (see, e.g., Hussinger, 2006), while others also consider lead times and product complexity (see, e.g., Hall et al., 2014). However, according to WIPO (2014), a prerequisite for trade secrets is that they be accompanied by confidentiality agreements or similar contracts. We therefore suggest a third category of semi-formal IPPMs that would contain trade secrets as well as confidentiality agreements and other contracts. This linkage is also confirmed by prior studies (see e.g. Hertzfeld et al., 2006). Some scholars signal the importance of contracts' content in collaborations (see e.g. Faems et al., 2008) and also find increased use of contracts in OI (see Hagedoorn and Ridder, 2012).

Additionally, previous research on appropriability is rather biased towards patents and secrecy (trade secrets) (see, e.g., Hall et al., 2014; Hussinger, 2006). The appropriability literature still has gaps about the potential complementarity of different types of IPPMs (see, e.g., West, 2006) and the relationship between openness and appropriability (Hagedoorn and Ridder, 2012; Hertzfeld et al., 2006; Laursen and Salter, 
2014). Although some previous studies suggest that firms' use of IPPMs in research partnerships is linked to factors such as the type of knowledge to be exchanged, the type of partners and the industry (see, e.g., Griffith et al., 2006; Hertzfeld et al., 2006), the literature has to our knowledge not provided sufficient and compelling evidence of how companies choose different IPPMs in collaborations with various types of partners. We thus propose a first research question regarding the above-stated gap:

RQ1 How does the use of different IPPMs influence firms' openness in terms of variety of partners and depth of collaboration with each type of partner?

\subsection{Partner location}

The contrast between increasingly globalised networks (Bititci et al., 2012; Dussauge and Garrette, 1995) and the patchwork of IP laws (Geller, 1998; Peukert, 2012) amplifies the tensions in the appropriability-openness relationship. This contrast further spotlights the partner location dilemma (see Huang and Rice, 2013; Kotabe et al., 2008; Liu et al., 2013). Additional arguments for including the geographical dimension in the analysis rest upon the understanding of OI as the crossing of firm boundaries (see, e.g., Chesbrough and Bogers, 2014) and Boschma's (2005) interpretation of boundaries as a type of proximity. Following this trail, Knoben and Oerlemans' (2006) framework suggests three main categories of proximity in interorganisational collaborations: organisational, technological and geographical.

The significance of geographical proximity in the context of OI has been analysed in several prior studies (e.g. Capaldo and Petruzzelli, 2014; Molina-Morales et al., 2014), but the concept of geographic proximity has not been clearly defined. Some studies refer to it in terms of pure distance, without distinguishing between country boundaries (e.g. Aslesen and Onsager, 2009; Jong and Freel, 2009; Teirlinck and Spithoven, 2008), while others compare national and international approaches (see, e.g., Arvanitis and Bolli, 2013; Patel et al., 2014). Moreover, there seems to be a geographical dilemma when it comes to firms' openness. Some previous studies advocate the benefits of collaboration with local partners (see, e.g., Simard and West, 2006), at times with specific types of partners, e.g. local suppliers could be favoured due to shorter lead times according to Roper and Crone (2003). Scholars have also previously called attention to the additional efforts and costs required to integrate knowledge from distant actors (see, e.g., Praest Knudsen and Bøtker Mortensen, 2011). On the other hand, previous studies point to the fact that knowledge is heterogeneously distributed among actors globally (Moodysson et al., 2008) and that distant partners are more likely to provide complementary knowledge due to their presumably less similar technological bases, thus stimulating innovation by blending diversified knowledge inputs (Arvanitis and Bolli, 2013; Berchicci et al., 2015). Finally, some studies even provide arguments that a balanced approach (both local and foreign partners) is more advantageous (Patel et al., 2014). Thus, the spatial distribution of partners seems to remain a dilemma.

In recent years the literature has highlighted the internationalisation of innovative activities (see, e.g., Sasaki et al., 2010), yet national intellectual property laws are more often drafted only for national purposes (Trimble, 2015). Several prior studies stress the importance of differences between international IP rights and the influences these might have on OI (West, 2006). More specifically, protecting knowledge internationally with formal and semi-formal IPPMs has been pointed out to be a complex and costly process 
(see, e.g., Lee, 2014; Trimble, 2015). However, empirical evidence is lacking on how partners' geographical location affects the appropriability-openness relationship. Some scholars emphasise the value of patents in international collaborations (Neuhäusler, 2012), while others observe tendencies towards informal appropriability prevail in global settings (Freel et al., 2009). The aforementioned differences between national IP laws may also trigger shifts in the choice of IPPMs or that of partners (Hagedoorn et al., 2005; Neuhäusler, 2012) and indeed previous studies indicate that firms' appropriability, the susceptibility to collaborate with external partners and the 'reach of cooperation' are interlinked (Freel et al., 2009). Yet there is scarce proof linking the distinct types of IPPMs to specific types of partners depending on location. Studies that investigate appropriability issues in collaboration with various types of partners (Arora and Merges, 2004; Belderbos et al., 2014; Veugelers and Cassiman, 2005) tend to overlook territorial aspects. Freel et al. (2009) predict a positive relationship between the importance of formal IPPMs and the reach of collaboration, yet their results confirm this only in the case of customer collaboration, while with other types of partners, i.e. suppliers and competitors, informal IPPMs prevail. An earlier study shows contrasting results relating to collaboration with competitors - more specifically a shift from informal IPPMs in national co-opetition to formal IPPMs with international competitors is identified in a sample of German manufacturing firms (Schmiele and Sofka, 2007). Other types of partners, such as universities or public partners have been conspicuously left out of similar analyses. One potential explanation is that collaboration with universities tends to be more locally focused (Freel et al., 2009; Veugelers and Cassiman, 2005). This review points out a gap in understanding how the use of particular IPPMs in collaboration with different partners varies when considering the location of the different partners. We therefore formulate the second research question:

RQ2 What are the effects of IPPMs on firms' openness (variety of partners and depth of collaboration) when taking into account the location (national or international) of partners?

The research questions and the core constructs are illustrated in the analysis model in Figure 1.

Figure 1 Analysis model (see online version for colours)

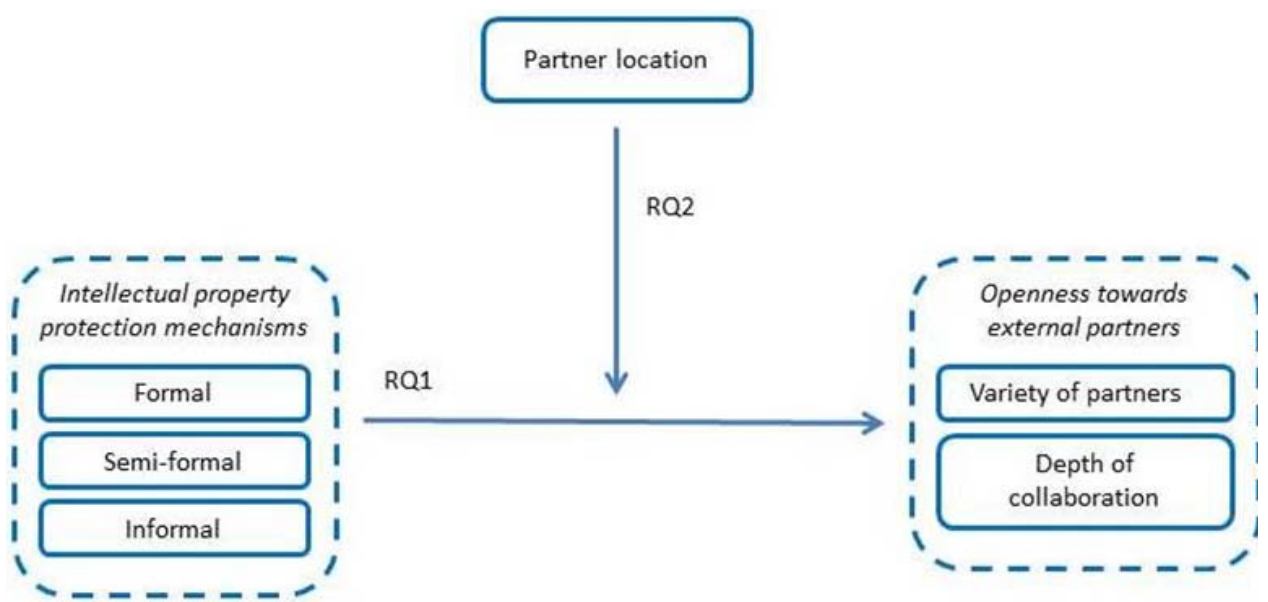




\section{Research methodology}

\subsection{Survey}

The paper relies on data from an international survey on OI that covered a sample of manufacturing firms (codes 10-32 and 98 in NACE Rev. 2) with more than ten employees in Italy, Finland and Sweden (see Bengtsson et al., 2015). Researchers from the three countries followed similar steps for the survey design and the data collection process, as recommended by Forza (2002) and others. A randomised stratified sample of 1,000 manufacturing companies was chosen in each of the three countries. In order to guarantee the representativeness of the sample, the researchers conducted probabilistic sampling (Babbie, 1990). The online survey was answered by R\&D managers or equivalent individuals knowledgeable about OI at some of the 415 firms that had previously engaged in innovation collaborations with external partners. More specifically, 152 answers were provided by Italian firms, 176 by Swedish companies and 87 by Finnish companies, thus representing an approximate rate of response of $13 \%$. A non-response bias analysis was performed for each of the three countries, but no significant dissimilarities were found between respondents and non-respondent firms. This analysis included comparison of industry types and firm size. We furthermore applied a so-called wave analysis (see, e.g., Rogelberg and Stanton, 2007), which showed no differences between responses to key survey questions from early and late respondents.

The number of employees in the studied firms varies between 10 and 56,000, with a mean value of 867 employees (standard deviation 4,239) and a median value of 50 employees. The survey concerns firms' collaboration with external partners in innovation (i.e. development of new products, services or processes) during the past five years. The questionnaire includes questions on strategy and motives, contextual factors, openness, relational factors and performance outcomes. The focus in the current paper is on questions that capture the use of appropriability strategies, the extent to which R\&D partners in the OI processes are international, and the variety and depth of partner collaboration. In order to improve the quality of the instrument, a pilot test of the questionnaire was done by colleagues and target respondents in selected firms.

\subsection{Constructs}

From the analysis model in Figure 1, we can see that the main constructs concern three types of protection mechanisms, the international nature of partners, and the variety and depth of partner collaboration. All answers are measured by seven-point Likert scales, ranging from $1=$ not at all to $7=$ to a very high extent. The protection mechanisms were captured via a question asking: 'Please indicate the extent to which your company uses the following IPPMs when collaborating with external partners in innovation activities'. Based on previous studies on IP appropriability strategies (e.g. Amara et al., 2008; Arundel, 2001; Hertzfeld et al., 2006), eight different mechanisms were suggested. In order to distinguish formal IPPMs such as patents from informal and semi-formal IPPMs, we conducted an exploratory factor analysis. The partner constructs capture which kind of partner(s) the firms collaborate with in OI (variety of partners) and how deep (intensive) the collaboration is with each of these partners. This way of capturing openness follows Laursen and Salter (2006), but we used a more fine-grained scale for 
measuring the depth of collaboration. The respondents were asked to rate the extent to which the firms collaborated with eight specified stakeholders, i.e. universities, innovation intermediaries, government agencies, customers, suppliers, consumers, competitors and companies in other industries, in innovation activities over the previous five years. The variety of partners was defined by summing up the number of partners that the firms have engaged in their OI processes (minimum 1, maximum 8 , median 5 , mean 5.26 and standard deviation 1.95). For the depth of collaboration construct, the eight partners were reduced in an exploratory factor analysis that resulted in two factors representing academic partners (including universities, innovation intermediaries and government agencies) and value chain partners. Companies in other industries were omitted in this analysis because of loading equally on the factors. Previous studies provide evidence that excluding competitors from the analysis of the appropriabilityopenness relationship might reduce the strength of this connection (see, e.g., Laursen and Salter, 2014). For this reason we include competitors as a separate group in our analysis. All factor loadings are displayed in Table 1. We notice that some Cronbach's alpha values are lower than 0.70, which weakens the strength of the model (Hair et al., 1992). All values are, however, above 0.60 .

Table 1 Factor analysis results

\begin{tabular}{|c|c|c|c|c|c|c|}
\hline & $\begin{array}{l}\text { Formal } \\
\text { IPPMs }\end{array}$ & $\begin{array}{l}\text { Semi-formal } \\
\text { IPPMs }\end{array}$ & $\begin{array}{l}\text { Informal } \\
\text { IPPMs }\end{array}$ & $\begin{array}{c}\text { Academic } \\
\text { partners }\end{array}$ & $\begin{array}{l}\text { Value chain } \\
\text { partners }\end{array}$ & $\begin{array}{c}\text { Innovation } \\
\text { ambition }\end{array}$ \\
\hline \multicolumn{7}{|l|}{ IPPMs } \\
\hline Patents & .783 & & & & & \\
\hline Designs & .807 & & & & & \\
\hline Trademarks & .717 & & & & & \\
\hline Copyrights & .580 & & & & & \\
\hline Trade secrets & & .773 & & & & \\
\hline $\begin{array}{l}\text { NDAs and } \\
\text { other contracts }\end{array}$ & & .883 & & & & \\
\hline $\begin{array}{l}\text { Product } \\
\text { complexity }\end{array}$ & & & .822 & & & \\
\hline Lead times & & & .873 & & & \\
\hline \multicolumn{7}{|l|}{ Partners } \\
\hline Universities & & & & .798 & & \\
\hline $\begin{array}{l}\text { Innovation } \\
\text { intermediaries }\end{array}$ & & & & .641 & & \\
\hline $\begin{array}{l}\text { Government } \\
\text { agencies }\end{array}$ & & & & .789 & & \\
\hline Customers & & & & & .798 & \\
\hline Suppliers & & & & & .788 & \\
\hline Consumers & & & & & .556 & \\
\hline
\end{tabular}


Table 1 Factor analysis results (continued)

\begin{tabular}{lcccccc}
\hline & $\begin{array}{c}\text { Formal } \\
\text { IPPMs }\end{array}$ & $\begin{array}{c}\text { Semi-formal } \\
\text { IPPMs }\end{array}$ & $\begin{array}{c}\text { Informal } \\
\text { IPPMs }\end{array}$ & $\begin{array}{c}\text { Academic } \\
\text { partners }\end{array}$ & $\begin{array}{c}\text { Value chain } \\
\text { partners }\end{array}$ & $\begin{array}{c}\text { Innovation } \\
\text { ambition }\end{array}$ \\
\hline $\begin{array}{l}\text { Innovation } \\
\text { ambition }\end{array}$ & & & & & \\
$\quad \begin{array}{l}\text { Prioritising } \\
\text { new product } \\
\text { and service } \\
\text { development } \\
\text { and innovation }\end{array}$ & & & & & .676 \\
$\begin{array}{l}\text { Having broad } \\
\text { product/market } \\
\text { portfolio }\end{array}$ & & & & & \\
$\begin{array}{l}\text { Having a broad } \\
\text { technology } \\
\text { portfolio }\end{array}$ & & & & & \\
\hline $\begin{array}{l}\text { Cronbach's alpha } \\
\mathrm{N}\end{array}$ & .774 & .729 & .689 & .628 & .842 \\
\hline
\end{tabular}

The partners' location was measured by a single item capturing to what extent (on a scale of 1-7) the R\&D activities are performed by external partners located abroad. Inspired by Patel et al.'s (2014) identification of a balanced approach, the variable was used to form three clusters with mean values of 1.37 for the group with mostly national partners (the 'national group'), 2.43 for the group with a mix of both national and international partners ('balanced group') and 5.12 for the group with mainly international partners ('international group'). The differences between the three groups are significant.

\subsection{Controls}

We used several control variables in our analysis. We include firm size, in terms of number of employees (the natural logarithmic value), following Neuhäusler (2012). We also add industry controls, since previous studies suggest appropriability differs across industry sectors (Hall et al., 2014; Hertzfeld et al., 2006). We divided the studied companies into four industry clusters, following the classification proposed by Eurostat and Statistics Sweden SCB (2014), i.e. low-tech (NACE 10-18 and 31-32), medium low-tech (NACE 19, 22-25), medium high-tech (NACE 20, 27-30), and high-tech (NACE 21 and 26). However, for 68 firms the industry sector was unknown. We use low-tech as baseline, resulting in four industry dummies, i.e. LowTech versus medLowTech, LowTech versus medHighTech, LowTech versus HighTech and LowTech versus NoInd. We also include controls for the three countries, as previous studies suggest that appropriability may vary significantly across national borders (Hagedoorn et al., 2005). Using Sweden as baseline, we arrived at two country dummies: SE versus IT and SE versus FI. The claimed strategic importance of product development represents an additional control called 'innovation ambition', formed from three items as previously shown in Table 1 and in line with Berchicci et al. (2015).

When we performed linear regression analysis, we identified no multicollinearity issues when testing the variable inflation factor (VIF) (Hair et al., 1992), nor did we find other violations of the assumptions for the regression analysis. The basic correlations 
between all regression variables are displayed in Appendix. To test for common method variance, we conducted a Harman single-factor test (Podsakoff et al., 2003). Seven different factors with eigenvalues greater than 1 emerged as a result of the exploratory factor analysis. The largest factor accounts for approximately $13 \%$ of the variance, while the seven factors together account for approximately $67 \%$ of the variance. Even though this test does not fully exclude the possibility, the result indicates that our analysis does not suffer from common method variance.

\section{Results}

Table 2 addresses the first research question and reveals how the use of IPPMs influences openness. The semi-formal IPPMs affect both the variety of partners and the depth of collaboration with academic partners. Formal IPPMs further explain the openness towards academic partners, while informal IPPMs explain the depth of collaboration with value chain partners. Neither type of IPPMs appears to be explanatory for co-opetition, but taking location into account might yield further evidence regarding this connection.

Table 2 Regressions on IPPMs' influence on firms' openness

\begin{tabular}{|c|c|c|c|c|}
\hline & \multirow{2}{*}{$\begin{array}{c}\text { Dependent variable }= \\
\text { variety of partners } \\
\text { All firms }\end{array}$} & \multicolumn{3}{|c|}{$\begin{array}{l}\text { Dependent variable }= \\
\text { depth of collaboration }\end{array}$} \\
\hline & & $\begin{array}{l}\text { Academic } \\
\text { partners }\end{array}$ & $\begin{array}{l}\text { Value chain } \\
\text { partners }\end{array}$ & Competitors \\
\hline \multicolumn{5}{|l|}{$I P P M s$} \\
\hline Formal IPPMs & .082 & $.100^{\wedge}$ & .055 & -.024 \\
\hline Semi-formal IPPMs & $.155^{* *}$ & $.272 * *$ & .075 & -.016 \\
\hline Informal IPPMs & .038 & -.036 & $.101^{\wedge}$ & .078 \\
\hline \multicolumn{5}{|l|}{ Controls } \\
\hline Size $\ln$ & $.185^{* *}$ & $.184 * *$ & .003 & -.042 \\
\hline $\begin{array}{l}\text { LowTech vs } \\
\text { medLowTech }\end{array}$ & $.121 *$ & $.118^{*}$ & .058 & .086 \\
\hline $\begin{array}{l}\text { LowTech vs } \\
\text { medHighTech }\end{array}$ & -.030 & -.008 & -.041 & -.031 \\
\hline $\begin{array}{l}\text { LowTech vs } \\
\text { HighTech }\end{array}$ & -.075 & -.087 & -.002 & -.033 \\
\hline LowTech vs NoInd & .011 & -.061 & .041 & .071 \\
\hline SE vs IT & -.070 & $.122 *$ & -.063 & $-.116^{\wedge}$ \\
\hline SE vs FI & .003 & -.042 & $-.161 * *$ & .022 \\
\hline Innovation ambition & $.125^{*}$ & $.095^{\wedge}$ & $.206^{* *}$ & $.121 *$ \\
\hline Adj $R^{2}$ & .167 & .213 & .111 & .018 \\
\hline $\mathrm{F}$ & 8,218 & 10,745 & 5,492 & 1,642 \\
\hline $\mathrm{N}$ & 397 & 397 & 397 & 397 \\
\hline
\end{tabular}

Notes: Significance levels: ${ }^{\wedge} p<.10,{ }^{*} p<.05,{ }^{* *} p<.01$.

$\mathrm{N}=397$ due to 18 cases with incomplete data. 
Tables 3 and 4 show the results for the second research question regarding the effects of IPPMs on openness depending on partner location. For both dimensions of openness in our analysis, i.e. variety of partners and depth of collaboration (academic partners and competitors), we find that formal IPPMs open up collaboration in international settings. Semi-formal IPPMs explain the partner variety (Table 3) and depth of collaboration with academic partners as well as value chain partners (Table 4) in national settings. Additionally, informal IPPMs influence the openness towards national value chain partners and competitors. For the balanced partners group there is no significance of any type of IPPMs on either dimension of openness, except for the semi-formal IPPMs explaining the depth of collaboration with the academic partners. We can notice that in Tables 2-4 most control variables have some explanatory value, i.e. that size, industry character and innovation ambition do explain openness.

Table 3 IPPMs' influence on variety of partners, when considering location (three groups)

\begin{tabular}{|c|c|c|c|}
\hline $\begin{array}{l}\text { Dependent variable }= \\
\text { variety of partners }\end{array}$ & $\begin{array}{c}1 . \\
\text { National } \\
\text { partners group }\end{array}$ & $\begin{array}{c}2 . \\
\text { Balanced } \\
\text { partners group }\end{array}$ & $\begin{array}{c}3 . \\
\text { International } \\
\text { partners group }\end{array}$ \\
\hline \multicolumn{4}{|l|}{ IPPMs } \\
\hline Formal IPPMs & .076 & .150 & $.307^{*}$ \\
\hline Semi-formal IPPMs & $.146^{\wedge}$ & .057 & -.044 \\
\hline Informal IPPMs & .074 & -.116 & .145 \\
\hline \multicolumn{4}{|l|}{ Controls } \\
\hline Size ln & $.211 * *$ & .142 & .076 \\
\hline $\begin{array}{l}\text { LowTech vs } \\
\text { medLowTech }\end{array}$ & .064 & .038 & -.065 \\
\hline $\begin{array}{l}\text { LowTech vs } \\
\text { medHighTech }\end{array}$ & -.057 & -.011 & .001 \\
\hline $\begin{array}{l}\text { LowTech vs } \\
\text { HighTech }\end{array}$ & -.076 & .044 & .037 \\
\hline LowTech vs NoInd & .052 & -.111 & -.221 \\
\hline SE vs IT & $-.226 * *$ & .202 & $-.407 * *$ \\
\hline SE vs FI & .004 & .167 & -.194 \\
\hline Innovation ambition & .035 & $.264^{*}$ & .229 \\
\hline $\operatorname{Adj} R^{2}$ & .190 & .120 & .203 \\
\hline $\mathrm{F}$ & 5,981 & 2,268 & 2,340 \\
\hline $\mathrm{N}$ & 235 & 103 & 59 \\
\hline
\end{tabular}

Notes: Significance levels: ${ }^{\wedge} p<.10,{ }^{*} p<.05,{ }^{*} p<.01$. 
Table 4 IPPMs' influence on depth of collaboration, when considering partners' location (three groups)

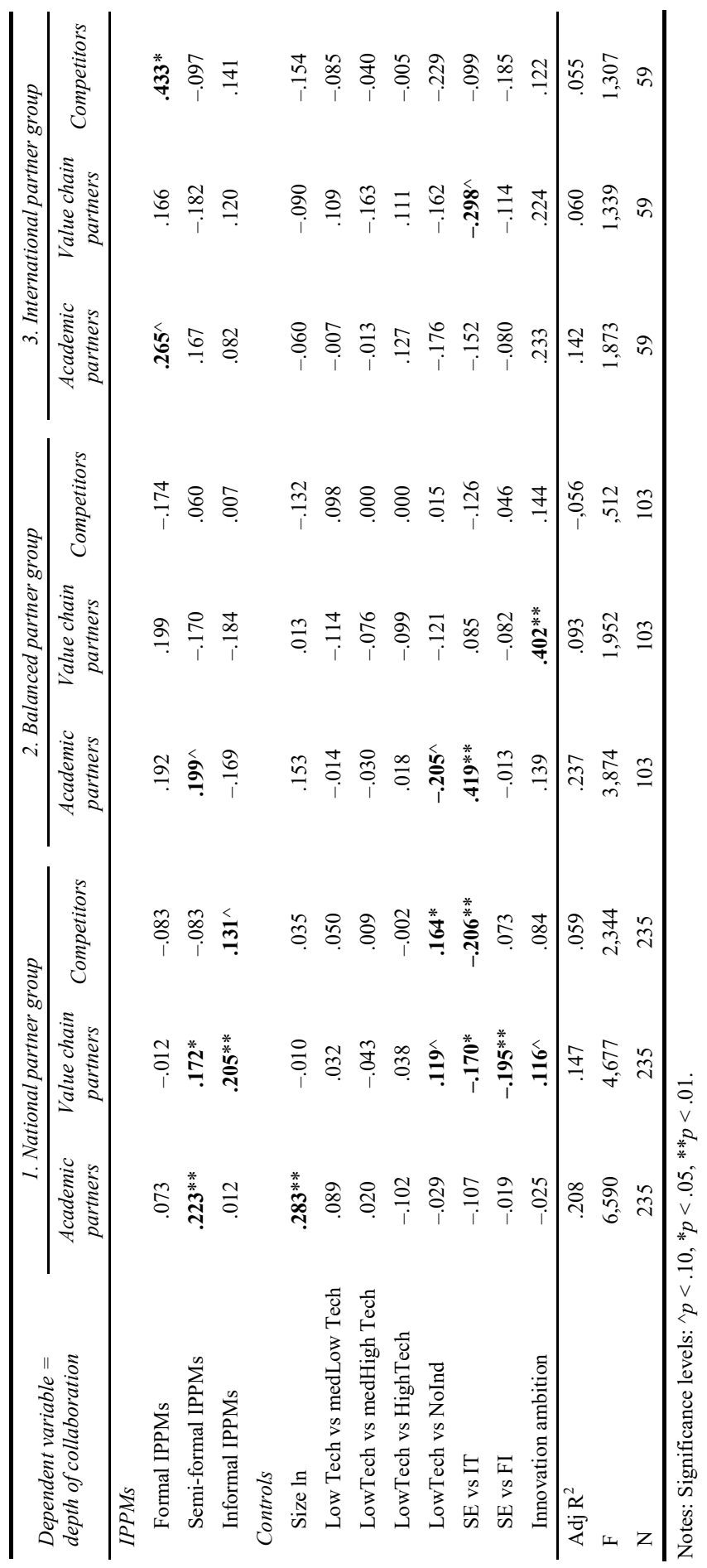




\section{Discussion}

We set out to investigate the appropriability-openness relationship; to do so we formulated two research questions. The first research question addresses the gap in the literature in understanding how the choice of various kinds of IPPMs explains openness towards different types of partners in innovation (see Laursen and Salter, 2014). The variety of partners is explained by semi-formal IPPMs, i.e. trade secrets and contractual agreements. This finding is in line with previous studies that suggest firms engaged in OI rely heavily on contracts (see, e.g., Hagedoorn and Ridder, 2012). For the depth of collaboration with academic partners, we find both formal and semi-formal IPPMs have significant positive effects. While our results contrast with studies that find the choice of appropriability does not affect firms' decision to collaborate with academic partners (see, e.g. Veugelers and Cassiman, 2005), we uncover potential explanations in more recent research. For instance, Belderbos et al. (2014) suggest that industry-university collaborations are characterised by the use of patents, i.e. formal IPPMs. They justify this by referring to the potential role of patents in easing collaboration by signalling the strength of the relationship between partners. This explanation is in line with the different roles of patents identified by Penin (2005). Moreover, previous studies have found the use of contracts could play a key role in building collaborations (Belderbos et al., 2014; Faems et al., 2008), which would explain the significant positive effects of both formal and semi-formal IPPMs on collaborations with academic partners for the firms in our sample. The depth of collaboration with value chain partners is mainly explained by informal IPPMs. This indicates that our results contrast with studies indicating that formal IPPMs, such as patents, are used in buyer-supplier relationships, particularly in the presence of incomplete contracts (see, e.g., Arora and Merges, 2004). One possible explanation for this deviation could relate to the different roles of patents, highlighted by for instance Penin (2005). That is, despite firms' use of patents in collaboration with value chain partners, it is likely that does not explain the openness. Cooperation with competitors does not appear to be explained by any of the three groups of IPPMs when only investigating the effects of appropriability mechanisms on firms' openness. This result will be further clarified when considering partner location.

Research question number two relates to the effects IPPMs have on firms' openness when also taking into account the extent of international partners. Previous research points out that due to differences in national intellectual property regimes (e.g. Hagedoorn et al., 2005) the appropriability-openness liaison might take different forms depending on the geographical (national or international) context of collaboration. We can add to this inquiry with a more fine-grained analysis. When differentiating between firms in our sample based on the extent of international partners they work with, we observe a pattern illustrating significant positive effects of formal IPPMs on both dimensions of openness considered in this study, i.e. variety of partners and depth of collaboration. Previous studies emphasise the use of patents in international settings, suggesting on one hand that patents could be a prerequisite for entering global markets, while on the other hand highlighting the disadvantage of disclosure in cross-border settings, which might cause unwanted spillovers (Neuhäusler, 2012). This further indicates that the risks of disclosure through formal appropriability are outweighed by its benefits in global markets. One such benefit, pointed out by Burk (2008), is viewing patents as codes for knowledge, which enables knowledge transfer and thus enables R\&D collaborations. 
Next, we will analyse in detail the results for the groups with mostly national or international partners. In the case of the balanced partners' group, none of the three types of IPPMs seem to explain either dimension of openness, with an exception for semi-formal IPPMs having strong positive effects on the depth of collaboration with academic partners. While research provides no tentative explanations for our findings concerning the balanced partners group, we believe the lack of significance of appropriability mechanisms could be related to other factors that influence openness. Since we are unable to capture such factors in our current analysis, we leave this particular outcome to be further clarified in future studies.

Regarding the first openness dimension considered in our study, we find that semi-formal IPPMs explain the variety of partners in national settings, whereas formal IPPMs positively influence openness towards a variety of international partners. While it appears that in global settings formal IPPMs illustrate their positive roles as prerequisites for entering global markets (Neuhäusler, 2012), coordinating functions (Penin, 2005) or acting as codes for knowledge (Burk, 2008), it seems that in national markets firms carefully weigh the risks of unwanted spillovers by disclosure via formal IPPMs. Hence, the use of semi-formal IPPMs rather explains openness in national settings, also confirming the findings of other prior studies (Faems et al., 2008; Hagedoorn and Ridder, 2012).

For depth of collaboration, we find effects on openness towards academic partners from the same type of IPPMs as in the case of partner variety, i.e. semi-formal IPPMs within national borders (and even for the balanced group) and formal IPPMs in international contexts. Thus, when including location in our analysis the demarcation between the use of semi-formal and formal IPPMs becomes clear, which adds to the first part of our analysis. Previous studies that investigate appropriability in industryuniversity collaborations show, for instance, that co-patenting, i.e. using formal IPPMs, enables cooperation by increasing market value and highlighting technological opportunities (Belderbos et al., 2014). Other scholars draw attention to the fact that universities' performance is often evaluated based on knowledge transfer to industry in the form of patents (Schartinger et al., 2002) or link the propensity to patent with predilection to collaborate with public research organisations (Neuhäusler, 2012). Our study contributes by providing more fine-grained results that indicate the formal IPPMs positively affect openness only towards foreign academic institutions. We further contribute to previous research by showing that the positive effects of contracts in collaborations (Belderbos et al., 2014; Faems et al., 2008) are mainly valid within national boundaries. Our results also indicate that the potential benefits of the roles of formal IPPMs, i.e. patents, to coordinate (Penin, 2005) or act as codes for knowledge (Burk, 2008) prevail in distant collaborations with foreign academic partners.

Considering the location of value chain partners also brings new evidence regarding the appropriability-openness relationship. We observe a positive but not significant effect of formal IPPMs on openness. The lack of significance could be attributed to a lower number of cases, which may in turn weaken the explanatory value of the model. The positive sign could be explained by previous findings of the importance of patents in buyer-supplier relationships (Arora and Merges, 2004). In addition, we find that in national settings both informal and semi-formal IPPMs are valid when working with value chain partners. Griffith et al. (2006) distinguish between the importance of appropriability for process versus product innovations, suggesting that the latter is more significant. Additionally, Griffith et al. (2006) point out that while suppliers are essential 
in providing process innovation, customers could prompt the product innovation. Roper and Crone (2003) further propose that local suppliers may be favoured due to shorter lead times. Hence the use of strategic (semi-formal and informal) IPPMs with national (local) value chain partners in our sample could be tentatively explained partly by the type of knowledge that these partners provide, and partly by the increased advantages of proximity in such collaborations. The appropriability mechanisms used in R\&D collaboration with value chain partners thus represents an avenue for further research.

Finally, when taking location into account, co-opetition is explained by informal IPPMs in national settings and by formal IPPMs across borders. This finding is in line with Schmiele and Sofka (2007), who find that (German) manufacturing firms switch their appropriability mechanisms from informal to formal when engaging in cross-border co-opetition. They clarify this outcome by pointing out the role of formal IPPMs in making knowledge 'visible, traceable and defendable'. However, other scholars show different effects of appropriability on near and far co-opetition, i.e. the use of informal appropriability with distant competitors (see, e.g. Freel et al., 2009) or the lack of influence appropriability mechanisms have on co-opetition (see, e.g. Dachs et al., 2008). We add to this research by illustrating the positive effects of formal IPPMs on co-opetition in international settings. Nevertheless, further research is needed to gain more in-depth understanding about the appropriability mechanisms used with various types of partners in innovation located near and far, and the reasons for those choices.

\section{Conclusions}

This study investigated the appropriability-openness relationship by analysing the effects of three different types of IPPMs on the openness of firms in terms of variety of partners and depth of collaboration with three types of partners. Furthermore, we investigated the potential moderating effect of the location of partners on the aforementioned relationship. Our study thus provides answers to recent calls for further research on the liaison between appropriability and openness (e.g. Laursen and Salter, 2014) and addresses the gap in research regarding the role of partners' location in the intricate context of simultaneously sharing and protecting knowledge.

One conclusion is that this study supplies new evidence that appropriability mechanisms, i.e. types of IPPMs, vary across openness dimensions (partner variety or depth of collaboration). More specifically, semi-formal IPPMs explain the variety of partners for the firms in our sample; the depth of collaboration with academic partners (including universities, innovation intermediaries and government agencies) is explained by both formal and semi-formal IPPMs. The use of contracts, i.e. semi-formal IPPMs, has been positively linked to collaborations (see, e.g., Faems et al., 2008; Hagedoorn and Ridder, 2012) and some previous studies further highlight the beneficial presence of patents in collaborations between firms and academic partners. However, the significant explanatory effect we found of informal IPPMs on depth of collaboration with value chain partners contrasts with previous studies that highlight the importance of patents in buyer-supplier relationships (see Arora and Merges, 2004).

A second conclusion is that a deeper analysis taking partners' location into account shows more fine-grained demarcations between choices of appropriability and openness. 
As predicted by previous studies, formal IPPMs become more valid in international settings (see Neuhäusler, 2012), more specifically for partner variety and collaboration with academic partners, as well as competitors. For competitors we observed a similar pattern to that found by Schmiele and Sofka (2007), i.e. that national co-opetition is explained by informal IPPMs, while collaboration with international competitors is positively affected by formal IPPMs. This pattern is further explained by studies addressing the potential additional roles of patents, besides that of protecting knowledge (see, e.g., Burk, 2008; Penin, 2005). Collaboration with foreign value chain partners also shows a positive but not significant link to formal IPPMs. This particular result calls for further research into appropriability in cross-border collaborations with value chain partners.

Our study also provides theoretical implications regarding the paradox of openness (Arrow, 1962; Laursen and Salter, 2014). According to our findings, the location of partners in innovation (either within or across national boundaries) constitutes a new, highly relevant dimension when analysing the appropriability-openness relationship. We further argue that considering partners' locations might help in pinpointing the actual occurrence or absence of the paradox of openness in OI collaborations. The potential paradox of openness could also be related to the multiple roles of patents described by previous studies. More specifically, besides the role of protecting knowledge in order to appropriate benefits from innovation (see Teece, 1986), it is likely that additional roles of patents to coordinate (Penin, 2005) or act as codes for knowledge (Burk, 2008) enable firms' openness, particularly in international settings.

Aside from the theoretical contributions, our study also has several practical implications. Our findings suggest that companies relying on either informal IPPMs, i.e. lead times and product complexity, or semi-formal IPPMs, that is trade secrets and various types of contracts, could open their organisational boundaries for collaboration with national partners. However, formal appropriability mechanisms, such as patents, seem mainly relevant to open up collaboration opportunities in international settings, as also suggested by prior research (see, e.g., Neuhäusler, 2012). For managers, this could imply that the additional costs required by formal protection of knowledge are outweighed in global collaboration settings, on one hand by the additional beneficial functions of such instruments as patents (see e.g. Penin, 2005), and on the other hand by the potential increased benefits of distant collaboration suggested by previous research (Arvanitis and Bolli, 2013; Berchicci et al., 2015). Managers should further be advised that when combining collaboration with national as well as foreign partners, the appropriability mechanisms alone do not seem to suffice for enabling openness.

The study is not without limitations. Although our regression analysis includes a variety of control variables, we did not take into account the potential explanatory effects of R\&D intensity (see, e.g., Jong and Freel, 2010). Therefore, future studies should also consider such independent variables when investigating the appropriability-openness relationship. Furthermore, our study only investigates the causality of the above-mentioned connection from one direction. Other scholars assert that causality goes both ways (see, e.g., Laursen and Salter, 2014), which we acknowledge as a further research topic. 


\section{References}

Amara, N., Landry, R. and Traoré, N. (2008) 'Managing the protection of innovations in knowledge-intensive business services', Research Policy, Vol. 37, No. 9, pp.1530-1547.

Arora, A. and Merges, R.P. (2004) 'Specialized supply firms, property rights and firm boundaries', Industrial and Corporate Change, Vol. 13, No. 3, pp.451-475.

Arrow, K. (1962) 'Economic welfare and the allocation of resources for invention', in Groves, H.M. (Ed.): The Rate and Direction of Inventive Activity: Economic and Social Factors, pp. 609-626, Princeton University Press, Princeton.

Arundel, A. (2001) 'The relative effectiveness of patents and secrecy for appropriation', Research Policy, Vol. 30, No. 4, pp.611-624.

Arvanitis, S. and Bolli, T. (2013) 'A comparison of national and international innovation cooperation in five European countries', Review of Industrial Organization, Vol. 43, No. 3, pp.163-191.

Aslesen, H.W. and Onsager, K. (2009) 'Knowledge bases, open innovation and city regions', The DRUID Summer Conference 2009, 17-19 June 2009, Copenhagen Business School, Copenhagen, Denmark.

Babbie, E. (1990) Survey Research Methods, Wadsworth, Belmont, CA.

Belderbos, R., Cassiman, B., Faems, D., Leten, B. and Van Looy, B. (2014) 'Co-ownership of intellectual property: exploring the value-appropriation and value-creation implications of co-patenting with different partners', Research Policy, Vol. 43, No. 5, pp.841-852.

Bengtsson, L., Lakemond, N., Lazzarotti, V., Manzini, R., Pellegrini, L. and Tell, F. (2015) 'Open to a select few? Matching partners and knowledge content for open innovation performance', Creativity and Innovation Management, Vol. 24, No. 1, pp.72-86.

Berchicci, L., de Jong, J.P. and Freel, M. (2015) 'Remote collaboration and innovative performance: the moderating role of R\&D intensity', Industrial and Corporate Change, DOI: 10.1093/icc/dtv031.

Bititci, U., Garengo, P., Dörfler, V. and Nudurupati, S. (2012) 'Performance measurement: challenges for tomorrow', International Journal of Management Reviews, Vol. 14, No. 3, pp.305-327.

Boschma, R.A. (2005) 'Does geographical proximity favour innovation?', Economie et Institutions, Nos. 6/7, pp.111-127,

Burk, D.L. (2008) 'The role of patent law in knowledge codification', Berkeley Technology Law Journal, Vol. 23, No. 3, pp.1009-1034.

Capaldo, A. and Petruzzelli, A.M. (2014) 'Partner geographic and organizational proximity and the innovative performance of knowledge-creating alliances', European Management Review, Vol. 11, No. 1, pp.63-84.

Cassiman, B. and Veugelers, R. (2006) 'In search of complementarity in innovation strategy: internal R\&D and external knowledge acquisition', Management Science, Vol. 52, No. 1, pp.68-82.

Chesbrough, H. and Bogers, M. (2014) 'Explicating open innovation: clarifying an emerging paradigm for understanding innovation', in Chesbrough, H. et al. (Eds.): New Frontiers in Open Innovation, pp.3-28, Oxford University Press, Oxford.

Chesbrough, H., Vanhaverbeke, W. and West, J. (Eds.) (2014) New Frontiers in Open Innovation, Oxford University Press, Oxford.

Chesbrough, H.W. (2003) 'The era of open innovation', MIT Sloan Management Review, Vol. 44, No. 3, pp.34-41.

Dachs, B., Ebersberger, B. and Pyka, A. (2008) 'Why do firms cooperate for innovation? A comparison of Austrian and Finnish CIS3 results', International Journal of Foresight and Innovation Policy, Vol. 4, No. 3, pp.200-229.

Dahlander, L. and Gann, D.M. (2010) 'How open is innovation?’ Research Policy, Vol. 39, No. 6, pp.699-709. 
Dussauge, P. and Garrette, B. (1995) 'Determinants of success in international strategic alliances: evidence from the global aerospace industry', Journal of International Business Studies, Vol. 26, No. 3, pp.505-530.

Faems, D., Janssens, M., Madhok, A. and Van Looy, B. (2008) 'Toward an integrative perspective on alliance governance: connecting contract design, trust dynamics, and contract application', Academy of Management Journal, Vol. 51, No.6, pp.1053-1078.

Forza, C. (2002) 'Survey research in operations management: a process-based perspective', International Journal of Operations \& Production Management, Vol. 22, No. 2, pp.152-194.

Freel, M., De Jong, J. and Chamberlin, T. (2009) 'Who co-operates for innovation, and where? Evidence from the 4th UK Innovation Survey', DRUID Conference 2009, Copenhagen, Denmark, 17-19 June 2009.

Gassmann, O. and Enkel, E. (2004) 'Towards a theory of open innovation: three core process archetypes', Proceedings of the $R \& D$ Management Conference, Lisbon, Portugal, 6-9 July 2004.

Geller, P.E. (1998) 'From patchwork to network: strategies for international intellectual property in flux', Duke's Journal of Comparative and International Law, Vol. 9, pp.69-90.

Griffith, R., Huergo, E., Mairesse, J. and Peters, B. (2006) 'Innovation and productivity across four European countries', Oxford Review of Economic Policy, Vol. 22, No. 4, pp.483-498.

Hagedoorn, J. and Ridder, A.K. (2012) Open Innovation, Contracts, and Intellectual Property Rights: An Exploratory Empirical Study, UNU-MERIT, Maastricht Economic and Social Research and Training Centre on Innovation and Technology, Maastricht, Netherlands.

Hagedoorn, J., Cloodt, D. and Van Kranenburg, H. (2005) 'Intellectual property rights and the governance of international R\&D partnerships', Journal of International Business Studies, Vol. 36, No. 2, pp.175-186.

Hair, J.F., Anderson, R.E. and Tatham, R.L. (1992) Multivariate Data Analysis, MacMillan Publishing, New York.

Hall, B.H., Helmers, C., Rogers, M. and Sena, V. (2014) 'The choice between formal and informal intellectual property: a review', Journal of Economic Literature, Vol. 52, No. 2, pp.1-50.

Hertzfeld, H.R., Link, A.N. and Vonortas, N.S. (2006) 'Intellectual property protection mechanisms in research partnerships', Research Policy, Vol. 35, No. 6, pp.825-838.

Huang, F. and Rice, J. (2013) 'Does open innovation work better in regional clusters?', The Australasian Journal of Regional Studies, Vol. 19, No. 1, pp.85-120.

Huizingh, E.K. (2011) 'Open innovation: state of the art and future perspectives', Technovation, Vol. 31, No. 1, pp.2-9.

Hussinger, K. (2006) 'Is silence golden? Patents versus secrecy at the firm level', Economics of Innovation and New Technology, Vol. 15, No. 8, pp.735-752.

Jong, J.P. and Freel, M. (2010) 'Absorptive capacity and the reach of collaboration in high technology small firms', Research Policy, Vol. 39, No. 1, pp.47-54.

Knoben, J. and Oerlemans, L.A.G. (2006) 'Proximity and inter-organizational collaboration: a literature review', International Journal of Management Reviews, Vol. 8, No. 2, pp.71-89.

Kotabe, M., Murray, J.Y. and Mol, M.J. (2008) 'Global sourcing strategy and performance: a "fit" versus "balance" perspective', Research in Global Strategic Management, Vol. 14, No. 14, pp.259-278.

Laursen, K. and Salter, A. (2005a) 'The paradox of openness. Appropriability and the use of external sources of knowledge for innovation', Academy of Management Conference, Honolulu, Hawaii, 5-10 August 2005.

Laursen, K. and Salter, A. (2005b) My Precious - The Role of Appropriability Strategies in Shaping Innovative Performance, DRUID Working Paper, No. 05-02.

Laursen, K. and Salter, A. (2006) 'Open for innovation: the role of openness in explaining innovation performance among UK manufacturing firms', Strategic Management Journal, Vol. 27, No. 2, pp.131-150. 
Laursen, K. and Salter, A. (2014) 'The paradox of openness: appropriability, external search and collaboration', Research Policy, Vol. 43, No. 5, pp.867-878.

Lazzarotti, V., Manzini, R. and Pellegrini, L. (2011) 'Firm-specific factors and the openness degree: a survey of Italian firms', European Journal of Innovation Management, Vol. 14, No. 4, pp.412-434.

Lee, E. (2014) 'The global trade mark', University of Pennsylvania Journal of International Law, Vol. 35, No. 4, pp.917-967.

Liu, J., Chaminade, C. and Asheim, B. (2013) 'The geography and structure of global innovation networks: a knowledge base perspective', European Planning Studies, Vol. 21, No. 9, pp.1-18.

Miozzo, M., Desyllas, P. and Miles, I. (2015) 'Combining appropriability mechanisms for innovation collaboration: evidence from a survey of knowledge-intensive service firms', DRUID Summer Conference 2015, Rome, Italy, 15-17 June.

Molina-Morales, F.X., García-Villaverde, P.M. and Parra-Requena, G. (2014) 'Geographical and cognitive proximity effects on innovation performance in SMEs: a way through knowledge acquisition', International Entrepreneurship and Management Journal, Vol. 10, No. 2, pp.231-251.

Moodysson, J., Coenen, L. and Asheim, B. (2008) 'Explaining spatial patterns of innovation: analytical and synthetic modes of knowledge creation in the Medicon Valley life-science cluster', Environment and Planning, Vol. 40, No. 5, pp.1040-1056.

Neuhäusler, P. (2012) 'The use of patents and informal appropriation mechanisms - differences between sectors and among companies', Technovation, Vol. 32, No. 12, pp.681-693.

Patel, P.C., Fernhaber, S.A., McDougall-Covin, P.P. and Van Der Have, R.P. (2014) 'Beating competitors to international markets: the value of geographically balanced networks for innovation', Strategic Management Journal, Vol. 35, No. 5, pp.691-711.

Penin, J. (2005) 'Patents versus ex post rewards: a new look', Research Policy, Vol. 34, No. 5, pp.641-656.

Peukert, A. (2012) 'Territoriality and extraterritoriality in intellectual property law', in Handl, G. and Zekoll, J. (Eds.): Beyond Territoriality: Transnational Legal Authority in an Age of Globalization, pp.189-228, Queen Mary Studies in International Law, Brill Academic Publishing, Leiden/Boston.

Podsakoff, P.M., MacKenzie, S.B., Lee, J.Y. and Podsakoff, N.P. (2003) 'Common method biases in behavioral research: a critical review of the literature and recommended remedies', Journal of Applied Psychology, Vol. 88, No. 5, pp.879-903.

Praest Knudsen, M. and Bøtker Mortensen, T. (2011) 'Some immediate - but negative - effects of openness on product development performance', Technovation, Vol. 31, No. 1, pp.54-64.

PRO INNO Europe (2007) 'A memorandum on removing barriers for a better use of IPR by SMEs', PRO INNO Europe. A Report for the Directorate-General for Enterprise and Industry by an IPR Expert Group [online] http://ec.europa.eu/enterprise/policies/innovation/files/ removing-barriers-better-use-ipr_en.pdf (accessed 26 August 2015).

Rigby, D. and Zook, C. (2002) 'Open-market innovation', Harvard Business Review, Vol. 80, No. 10, pp.80-93.

Rogelberg, S. and Stanton, J. (2007) 'Understanding and dealing with organizational survey non response', Organizational Research Methods, Vol. 10, No. 2, pp.195-209.

Roper, S. and Crone, M. (2003) 'Knowledge complementarity and coordination in the local supply chain: some empirical evidence', British Journal of Management, Vol. 14, No. 4, pp.339-355.

Sasaki, H., Sakata, I., Kajikawa, Y. and Tomobe, H. (2010) 'Network of international intellectual property rights research activity for national IP policy', Technology Management for Global Economic Growth (PICMET), 2010 Proceedings of PICMET '10, IEEE, pp.1-7.

SCB (Statistics Sweden) (2014) Innovationsverksamhet i svenska företag 2010-2012, Statistiska centralbyrån, Stockholm. 
Schartinger, D., Rammer, C., Fischer, M.M. and Fröhlich, J. (2002) 'Knowledge interactions between universities and industry in Austria: sectoral patterns and determinants', Research Policy, Vol. 31, No. 3, pp.303-328.

Schmiele, A. and Sofka, W. (2007) Internationalizing R\&D Co-opetition: Dress for the Dance with the Devil, ZEW Discussion Paper No. 07-045, University of Mannheim, Mannheim, Germany.

Simard, C. and West, J. (2006) 'Knowledge networks and the geographic locus of innovation', in Chesbrough, H. et al. (Eds.): Open Innovation: Researching a New Paradigm, pp.220-240, Oxford University Press, Oxford.

Teece, D.J. (1986) 'Profiting from technological innovation: implications for integration, collaboration, licensing and public policy', Research Policy, Vol. 15, No. 6, pp.285-305.

Teirlinck, P. and Spithoven, A. (2008) 'The spatial organization of innovation: open innovation, external knowledge relations and urban structure', Regional Studies, Vol. 42, No. 5, pp.689-704.

Trimble, M. (2015) 'Advancing national intellectual property policies in a transnational context', Maryland Law Review, Vol. 74, No. 2, pp.203-257.

Trott, P. and Hartmann, D. (2009) 'Why “open innovation" is old wine in new bottles', International Journal of Innovation Management, Vol. 13, No. 4, pp.715-736.

Veugelers, R. and Cassiman, B. (2005) 'R\&D cooperation between firms and universities. Some empirical evidence from Belgian manufacturing', International Journal of Industrial Organization, Vol. 23, No. 5, pp.355-379.

Von Hippel, E. (2005) Democratizing Innovation, MIT Press, Cambridge, MA.

West, J. (2006) 'Does appropriability enable or retard open innovation?', in Chesbrough, H. et al. (Eds.): Open Innovation: Researching a New Paradigm, pp.109-133, Oxford University Press, Oxford.

WIPO (2014) How are Trade Secrets Protected?, World Intellectual Property Organization [online] http://www.wipo.int/sme/en/ip_business/trade_secrets/protection.htm (accessed 26 August 2015). 


\section{Appendix}

\section{Correlations between variables}

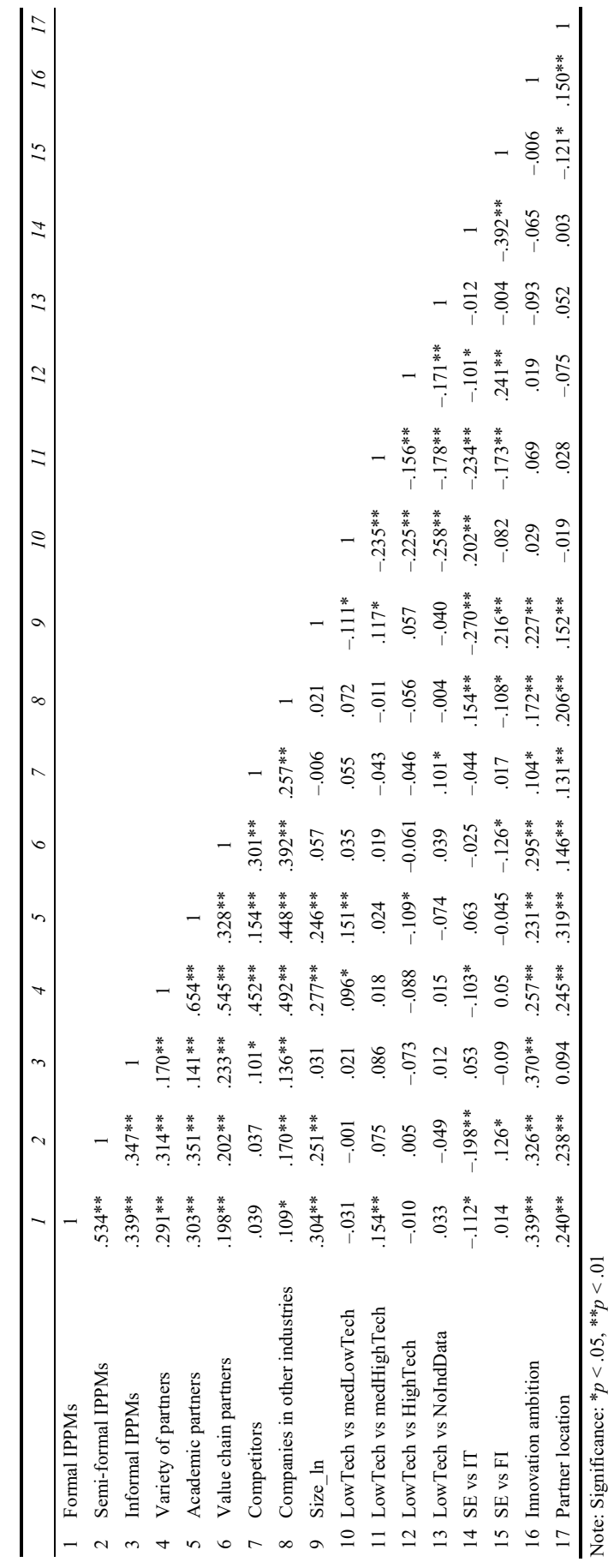

